\title{
Non-compaction cardiomyopathy - complications and long-term outcomes: a single-center experience
}

\author{
(1) Vlatka Rešković \\ Lukšić1*, \\ (D)Marija Mance', \\ (DZZvonimir Ostojić' , \\ (DDejan Došen', \\ Divan Bitunjac², \\ DKristina Gašparović1, \\ DiDadranka Šeparović \\ Hanževački' \\ 'University of Zagreb School \\ of Medicine, University \\ Hospital Centre Zagreb, \\ Zagreb, Croatia \\ ${ }^{2}$ General Hospital “Dr. Josip \\ Benčević" Slavonski Brod, \\ Slavonski Brod, Croatia
}

\begin{abstract}
KEYWORDS: non-compaction cardiomyopathy, arrythmia, thromboembolic event, prognosis CITATION: Cardiol Croat. 2019;14(9-10):223. | https://doi.org/10.15836/ccar2019.223

*ADDRESS FOR CORRESPONDENCE: Vlatka Rešković Lukšić, Klinički bolnički centar Zagreb, Kišpatićeva 12, HR10000 Zagreb, Croatia. / Phone: +385-1-2367-491 / E-mail: vlatka.reskovic@gmail.com

ORCID: Vlatka Rešković Lukšić, https://orcid.org/0000-0002-4721-3236 • Marija Mance, https://orcid.org/0000-0003-1542-2890 Zvonimir Ostojić, https://orcid.org/0000-0003-1762-9270 • Dejan Došen, https://orcid.org/0000-0002-2641-4768 Ivan Bitunjac, https://orcid.org/0000-0002-4396-6628 • Kristina Gašparović, https://orcid.org/0000-0002-1191-4831 Jadranka Šeparović Hanževački, https://orcid.org/0000-0002-3437-6407
\end{abstract}

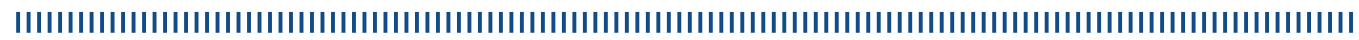

Aim: To investigate prevalence of arrythmias and thromboembolic events, as well as long term outcomes among patients diagnosed and treated of non-compaction cardiomyopathy (NCC) according to current recommendations in University Hospital Centre (UHC) Zagreb.

Patients and Methods: A single center retrospective study was conducted. Patients newly diagnosed with NCC in UHC Zagreb during period 2009-2018 were analyzed. The diagnosis was confirmed by both echocardiography and cardiovascular magnetic resonance. Hospital database and charts were used for clinical data, echocardiography data was obtained from digital database using EchoPac. Patients were followed-up clinically and by the means of echocardiography.

Results: 32 patients (pts), 18 men (53.25\%) were included. At the time of diagnosis (baseline), mean age was $47.7 \pm 15.4$ years, majority of pts (84.38\% of pts, $\mathrm{N}=27$ ) were in functional NYHA class $\geq 2$, with mean NT-proBNP values of $3870 \pm 6619 \mathrm{ng} / \mathrm{L}$. Echocardiography revealed reduced left ventricular systolic function; baseline ejection fraction (EF) was $27.52 \pm 11.94 \%$. Patients were discharged with heart failure therapy: beta-blockers (30 pts, $93.75 \%$ ), angiotensin-converting enzyme inhibitors or angiotensin receptor blockers (29 pts, 90.63\%), angiotensin receptorneprilysin inhibitor (1 pts, 3.13\%), mineralocorticoid receptor antagonists (28 pts, $84.38 \%)$; and 26 pts (81.25\%) required symptomatic diuretic use. Cardiac resynchronization therapy with defibrillator was implanted in 11 pts (34.38\%) and implantable cardioverter defibrillator (ICD) in 16 pts (50\%). At baseline, 9 pts (28.13\%) were already receiving anticoagulation due to previous thromboembolic events (Table 1). At discharge, 17 pts (53.13\%) were anticoagulated (warfarin in 14 pts, $82.35 \%$, novel direct oral anticoagulants in 3 pts, $17.65 \%$ ). Mean follow-up period was $3.42 \pm 3.31$ years. At the end of follow up period, functional improvement was observed: $21.88 \%(\mathrm{~N}=7)$ pts were in NYHA $\geq 2$ status ( $p<0.05)$, with manifest, but statistically nonsignificant reduction of NT-proBNP levels $(1260 \pm 2266 \mathrm{ng} / \mathrm{L}, \mathrm{p}=0.063)$. Control echocardiography revealed significant improvement in EF $(40.24 \pm 11.39 \%, \mathrm{p}<0.001)$. There were no new thromboembolic events. While arrythmias were common at the time of diagno-

\section{RECEIVED:}

September 2, 2019

ACCEPTED:

September 16, 2019

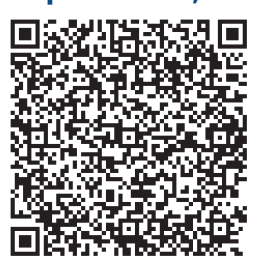

sis (Table 1), there was only one ICD activation during follow-up. None of the pts have died, 1 patient received heart transplant and 2 were implanted with left ventricular assist device.

Conclusion: Optimal medical treatment in patients with $\mathrm{NCC}^{1}$ corresponds with good long-term outcomes, functional improvement, and low risk of recurrent thromboembolic events or malignant arrythmias.

LITERATURE IIIIIIIIIIIIIIIIIIIIIIIIIIIIIIIIIIIIIIIIIIIIIIIIIIIIIIIIIIIIIIIIIIIIIIIIIIIIIIIIIIIIIIIIIIIIIIIIIIIIII

1. Carrilho-Ferreira P, Almeida AG, Pinto FJ. Non-compaction cardiomyopathy: prevalence, prognosis, pathoetiology, genetics, and risk of cardioembolism. Curr Heart Fail Rep. 2014 Dec;11(4):393-403. https://doi.org/10.1007/s11897-014-0227-3 